\title{
Approaches for Developing Generic Skills in Building Technology Graduates for Global Competitiveness
}

\author{
Jane Itohan Oviawe*, R. Uwameiye \\ Department of Vocational and Technical Education, Ambrose Alli University, Edo State, Nigeria \\ ${ }^{*}$ Corresponding author, e-mail: janeoviawe98@gmail.com
}

\begin{abstract}
The need to inculcate generic skills into graduates to meet the demands of the ever dynamic workplace has been of concern to stakeholders in education and the world of work. This concept of a global competitiveness, and generic skills were reviewed and discussed. This paper also examined the importance of generic skills; and factors influencing generic skills development among graduates were highlighted. This factors calls for different approaches and shift in pedagogy in developing generic skills for global competitiveness which include: change in instructional delivery, from the traditional method of instruction to cooperative learning model. It also involves integration and contextualized learning, creating world class spaces for learning, enhanced utilization of technology and inclusive learning and teaching environment for producing global workers in building technology.
\end{abstract}

Keywords: building technology, generic skills, global competitiveness

How to Cite: Oviawe, J. I., \& Uwameiye, R. (2020). Approaches for Developing Generic Skills in Building Technology Graduates for Global Competitiveness. Journal of Vocational Education Studies, 3(1), 25-38. DOI: https://doi.org/10.12928/joves.v3i1.1754.

\section{INTRODUCTION}

Building technology is program of study that is offered in higher institutions of learning and is concerned with the extensive technological skills which go hand in hand with the capacity to manage people, tools, machines and products in order to carry out building construction tasks professionally and successfully. It is aimed at producing technicians who will be able to perform basic functions in Building Technology practice, both in the private and public sector. The objectives of the program are to produce graduates that will assist the professional builders in the areas of: (1) production of simple buildings; (2) maintenance of simple buildings; (3) management of small projects; (4) costing of simple construction works; (5) cost control techniques in minor construction and engineering works; and (6) selection of materials and technicians for new building systems (National Board for Technical Education (NBTE), 2007). These objectives emphasized the acquisition of appropriate knowledge, skills and the development of mental, physical and social abilities and competencies as equipment for the individual to live in and contribute to the development of the society (Federal Republic of Nigeria (FRN), 2013).

Building technology shares the same goal with technical vocational education and training (TVET) as stated by the FRN (2013) in her national policy on education. TVET is a comprehensive term referring to those aspects of educational process involving, in addition to general education, the study of technologies and related sciences and acquisition of practical skills, attitudes, understanding and knowledge relating to occupations in various sectors of economic and social life (FRN, 2013). The expected outcomes comprise of: pursuing further education, setting up their own businesses or securing employment. The realization of these goals principally depends on the quality of graduates and their awareness of societal and workplace demands for future impacts in the face of technological development. 
Today's workplace environment is dynamic due to economic and technological factors. The impacts of globalization and advancement in technology have altered the global state where funds are used to significantly boost the development of a nation's infrastructure. Globalization is the most powerful economic factor influencing the workplace in all parts of the world. This does not only impact on large businesses globally, but also on students graduating from schools. These school leavers face a world of work (whether in the private or public sector that is decidedly different from a generation ago and the hard truth is that they need to contend with these alterations in an attempt to get ready for contemporary needs of the current day workplace.

\section{LITERATURE REVIEW}

\section{Globalization and its Effect in Today's World of Work}

Globalization has brought various demands on the skill of staffs to cope with the requirements of the global work force. Today's workers are being asked to learn new technologies to develop innovative techniques, to cross-function in work teams, to trouble shoot, among others. Shafie \& Nayan (2010) asserted that employers globally require staff highly trained with generic, technical and academic skills to meet the demands of the dynamic changes in technology, increase in social university and global competition. Employers of all kinds require their workforce to work readily and confidently across worldwide operation, using a global outlook to consider new opportunities and challenges.

Professor Charles Soludo lamented that Nigerians are not employable due to poor standard of education (Ajuluchukwu, 2014). They reported that about $60 \%$ of graduates being produced from the Nigerian universities were not qualified for employment at the global level. They added that the then President of Nigeria Alhaji Umaru Musa Yar'adua commented that millions of graduates from educational institutions of higher learning in the labour market are not qualified to be employed. Olatunji (2009) also reported that Sam Egwu and then Minister of Education also posited that $80 \%$ of the nation's graduates are unemployable hence only $20 \%$ of the graduates are employable. To this end, Ocho (2010) stated that a look at Nigerian newspaper and other news media gives an impression that the value for societal survival and growth through education are nonexistent in Nigeria.

Reviewing the employers' of labour's report, Nwaoku \& Tom (2009) posited that the employers of labour complained about considerable fall in the standard of university education over the past decades to further bring home the situation. They reported that the employers of labour stated that a university degree is no longer a guarantee to effective communication skills and technical competencies. They suggested that in this era of globalization, tertiary institutions must try their best to make their curriculum relevant to the present society. Employers need employers who can assimilate organization values and operate comfortably with the technological and cultural demands of the world of work.

Developments in technology have significant effects on the teaching and learning of building technology. To this end, Kaufman (2013) posited that technology creates a vital pressure for change. This is, changing both what we need to know and how we come to know it. Some of the developments in building technology are the movement from paper and pencil drafting to Automated Computer Aided Designs (AutoCAD); carton, wood and glue modelling to Building Information Modelling (BIM); structural and sectional detailing to structural analysis with software among others. Expertise to solve problems using technology is thus a core requirement of the generic skills thus information and communication technology (ICT). Similarly, Larson and Miller in Kaufman (2013) argued that of great importance is for students to be able research, organize, evaluate and communicate information with technology. The need of technology therefore transcends 
'playing with gadgets' (Larson, Miller \& Ribble, 2010) to include personal responsibility, personal productivity, adaptability, creativity, collaboration and communication. It is worth noting that knowledge and information in this era of technology also transcend individuals. Therefore, the availability and accessibility of the Internet affords every building technology student the opportunity to reach out beyond the class boundaries and contribute to the body of knowledge thereby overriding students' passiveness. In the face of individual contributions towards the actualization of a given task/building project, the importance of collaborative intelligence is attained, which in turn enhances collective learning.

A way of addressing these issues is through the development of generic skills in schools as staffs with knowledge and much needed skills sets profit from integrating into the global workforce, on the other hand, staffs without the necessary knowledge and skills are left behind. Hence, if Nigeria wants to compete globally, her graduates need to have competencies as well as capabilities to be able to work across national borders, manage complex relationships and understand global aspects of the workplace. Thus, this paper is poised to unravel from literature the generic skills associated with employability globally for building technology graduates. Also strategies for developing generic skills in building technology students for global competiveness were addressed.

\section{Global Competitiveness}

The dynamism of the society with its attendant globalization has resulted in a world where competitiveness is ranked on the basis of knowledge and skills which in turn has a greater participation in the productive activities. Competitiveness is a nation's capacity to produce, create and distribute products and services when trading internationally while achieving increase in return in its resources (Sargsyan, 2017).

Global competitiveness is a multi-dimensional notion and has diverse definitions. It focuses on assessing a nation's appeal and its participation in processes globally of supply and demands in the sense that it concerns itself with the degree of which its citizenry are being demanded to provide services internationally and how much foreigners are being attracted into the country's educational institutions, where we provide services and training (Sargsyan, 2017). It is the ability of a country's industries and entrepreneurs to produce goods and services that can be sold at competitive prices to other nations. In the context of this paper, global competitiveness is the ability of the Nigerian educational system to produce human capital (building technology graduates) that has the capacity to innovate and compete effectively in a knowledge-driven economy towards meeting global standards. These graduates must possess the requisite knowledge, competencies, skills, attitudes and values that are substantially comparable with global benchmark and provide Nigeria the requisite innovation for development. This is because today's world of work has increased channels and access to global customers through globalization. This has increased workforce mobility, thus making knowledge a global commodity.

Given the significance in the maintenance of global competitiveness, different country's focus their policies to be more competitive and carving out their place in the world globally. Therefore, the major goal of a nation involves establishing environments that foster wellbeing of citizens that addresses laws, environmental issues, safety and health. Undeniably, achieving this goal is through education. Hence, it is vital for governments to pursue and foster an all-inclusive approach towards education, giving its citizens the ability to competent in the provision of labour and rendering services to the larger society and also be able to attract resources and services by foreigners.

The most fundamental factor of the global competitiveness is expressed in education (TVET and building technology inclusive). Education becomes a propulsive force in the 
process of creating technology and providing sustainable development and it affects the competitiveness of citizens locally and globally. Education brings and strengthens change in any society at any time. Today, competence in the technological workplace provides competitive advantage to countries which can create and manage it. To this end, Keser (2015) asserted that to every respect of the knowledge age, the pursuit of innovation and realization of economic development depends on the work force having received quality and functional education.

Education is vitally fundamental in the development of production systems, implementation and management of new technologies. For the citizens to meet up with these expected roles, the type and quality of education provided must be deliberately designed and fashioned to achieve the expected end which is different from the colonial aim of education for educating the Nigerian child. At first, the expected end was ability to read and write. Today, the expected end of education and educating is much more than that. The functional and social skills required in the past and that needed today differ markedly.

The competitiveness of citizens globally, is facilitated by education, stressing the need for citizens to be educated to become competitive. The rationale behind this states that, to be globally competent, one has to be competitive globally. An individual's skills and competence should be superior or equal to any other one from other countries, especially those who have attended the same level of education with you and are asking to offer the same services on the same condition. Global competitiveness education is a form of education that can transform the lives of learners in terms of the necessary knowledge, technical and generic skills as well as work experiences that is desirable globally. This form of education would enable learners to be citizens globally who can fit into the global system and offer solutions to challenges globally (Ikoro \& Ezeanyim, 2017).

\section{Concept of Generic Skills}

There is lack of agreement on what is meant by generic skills as evidenced by many terms used to describe them, for instance, 'employability skills', 'soft skills', 'graduate attributes' and 'key skills/competencies', 'core skills', essential skills', 'transferrable skills', and 'employability skills'. Generic skills are 'transferable' skills or capabilities which allow skills learned in one context to be fairly readily transferred to another, which allow people to succeed in a wide range of different tasks and jobs (Bennett, 2006). They comprise a suite of 'transferable' skills independent of the occupational sectors and organizations in which individuals work, and which contribute to an individual's overall employability by enhancing their capacity to adapt, learn and work independently (Greatbatch \& Lewis, 2007). Generic skills are those skills that apply across a variety of jobs, organizations and sectors. Generic skills are needed not only to secure employment but also to progress within an organization or on the job. Generic skills include:

1. Fundamental skills: technology skills, using numbers and literacy

2. People-related skills: leadership skills, customer service skills, team working skills, negotiating skills, influencing skills and communication skills.

3. Conceptualizing/thinking skills: reflective skill, creative, innovative thinking, learning skills, organizing and planning skills, problem solving, managing information.

4. Personal skills and attributes: ability to manage personal time and deal with pressure, sensible, well presented, flexible, loyal, committed, resourceful, honest, responsible, reliable, motivated, adaptable and being enthusiastic.

5. Skills related to the business world: business awareness, commercial awareness, enterprise skills and innovation skills.

6. Community skills: citizenship abilities

While there is general agreement that generic skills are important, there is no definite list of such skills. Although generic ability framework differs in form of specific 
skill and qualities included. Majority of basic skills comprise of thinking/conceptualizing skills and people related skills. Recently, some skills created by owners of firms highlight personal attributes and skills.

\section{Importance of Generic Skills to Employers of Labour}

Technological advancement has brought about the growth in customers' sophistication and enhanced competitiveness. Today's employers are increasingly seeking generic skills alongside technical skills as a means of developing a workforce that is able to cope with: increasingly complex work practices; team working; reduced supervision; greater job flexibility and rotation and increased interaction with customers. Generic skills are important because jobs today require flexibility, initiative and the ability to undertake many different tasks. They are not as narrowly defined and prescribed as in the past and generally they are more service oriented, making information and social skills increasingly important. According to Greatbatch \& Lewis (2007), the following are some of the reasons for acquisition of generic skills:

1. Decentralization of supply chain management and schemes require commercial and business awareness from all workers, team leadership and higher communication;

2. The rise in jobs in retail, finance and business sectors all require more workers with communication skills be able to elucidate things and resolve difficulties peculiar to the needs of clients.

3. Industrial staffs increasingly work in teams or cells and demands communication internally;

4. Skilful staffs often work with complicated processes, requiring problem solving skills, reasoning and greater thinking in an attempt to deal with faults or operate machinery;

5. Standardizing computer based packages in various call centres, banking and insurance stresses the importance of attitudes such as personal organisation, judgement and confidence and communication skills.

Employers continuously strive to understand relations in the office, communicating which includes arranging arguments and convincing others, complementing group task with the capacity to get on individually, appropriate behaviours and self-management skills. Attributes that are valued consist of willingness to learn, get on with people, be creative, imaginative, dependable, committed and being able to work under pressure.

Organizations look to train, recruit and re-train staffs with these skills and as such education programs that help to achieve this, provide students with much needed advantage in the work place. Providers of education favour generic skills because it encourages students to be self-directed and more reflective.

\section{Factors influencing Generic Skills Development among Graduates}

The importance of developing students' generic skills cannot be over emphasized. Graduate employer in the business world face increase in competition and as such demand more from graduate recruits compared to prior periods (Kelly, 2006 in Oviawe \& Adeola, 2017). To this end, Crebert (2006) in Oviawe \& Adeola (2017) asserted that the fact that the skills of new graduates are now important compared to past years as the workforce now boosts of more flexibility, technology dependent and insecure as opposed to prior periods. Smith \& Kruger (2008) outlined the most important factors that influence the general skills of graduates and development as "external factors", development and internal factors, as presented in Table 1. 
Table 1. Factors influencing generic skills development of graduates

\begin{tabular}{ll}
\hline \multicolumn{1}{c}{ External trends and developments } & \multicolumn{1}{c}{ Internal Factors } \\
\hline Intense competition in the labour market & Changes in people-management policies \\
Large supply of graduates from universities & Graduate interest to develop leadership skill \\
A 'consumerism' attitude of graduates views & More self-managed careers as opposed to \\
about jobs/careers & hierarchical structures \\
Improving the employability of graduates & Changing career philosophies \\
Concerns by employers on the quality of & Organizational and structural changes (such \\
higher graduates education output & as new technologies and globalization) \\
Increased use of technology in recruitment & Differences in the way of learning as seen \\
processes & $\begin{array}{l}\text { and facilitated by organizations } \\
\text { Changing business practices and jobs roles }\end{array}$ \\
& $\begin{array}{l}\text { Collaborative environments characterized by } \\
\text { teamwork and leadership }\end{array}$ \\
\hline
\end{tabular}

\section{Employers' Expectations from Employees}

In order to identify employers' requirements most tertiary institutions globally carry out surveys on the needs of employers. Employers traditionally reveal the level of skill they require or need from new recruits. Tertiary institutions in Nigeria can also do conduct employers' skills requirement survey to identify the real needs in order to strengthen their students' skills and attributes for employability. An example of Employers' need survey according to Welgamage (2009) can be seen in Table 2.

Table 2. Employers' expectations from employees

\section{S/N Employers' Expectations from Employees}

1. Risk Assessment Management: this involves the capacity to evaluate different courses of action in line with its related risks, consequences, to detect different ways of reducing the inherent risk.

2. Understanding the Work place: this involves understanding the workplace expectations, dynamics and values

3. Career planning: this is the ability of staff to manage their careers in a workplace that constantly changes.

4. Work Diversity: this is the ability to understand, tolerate and respect various philosophies of life, values, points of view and constructively deal with individuals different from yourself.

5. Problem solving: the ability to recognise, arrange and solve problems. This involves asking the right questions, examine the various aspects of a problem and determine the best solutions.

6. Team skills: the capacity to effectively work as a team member and understand the elements that make the team a success.

7. Learning skills: learning from a wide array of sources which includes competences like thinking critically, organising information, and learning what matters.

8. Self-understanding: the capacity to know about personal traits and strengths

9. Leadership skills: the ability to motivate, influence and lead others.

10. Time Management: the capacity to handle multiple tasks at once and set targets and allocate time judiciously in an attempt to meet various deadlines.

Source: Weligamage (2009)

Hence, the generic skills of individualized knowledge creation, teamwork, team management, team spirit, etc with wider community of learners can only be developed through cooperation and are sustained with clarity of its model. 


\section{Approaches in Developing Generic Skills for Global Competitiveness}

The need for education for global competitiveness has instigated changes and has made the recognition and the combination of global challenges and issues as part of the curriculum imperative. The demand of TVET (building technology inclusive) in today's world of work cannot be met by bricks and mortar approach alone. A new approach of learning is required for the knowledge and skills required in the ever dynamic world of work. Educating individuals to be competitive globally indicates teaching learners to be citizens globally by not just being aware of these concerns but much more than that, being able to effectively participate in proffering solutions. Students should strive to understand the interdependence of world systems as well as believe solving the global challenges is achievable. These can be done through the following ways.

\section{Change in Instructional Delivery}

Integrating of generic skills into the curriculum of building technology will require substantial change including those that relate to new learning technologies, flexible learning strategies and assessment practices. Another reason for seeking for a change in delivery method is the emerging skills in today's world of work which employers perceived as lacking among new entrants. The building technology curricular need to be shifted from the traditional method to new way of teaching in order to meet employers' needs. Today's teaching requires new approaches that favour generic learning and the ability to develop intellectual skills far beyond memorization of facts, formulas and events (Omollo, Nyakrura \& Mbalamula, 2017). For Nigeria educational system to produce globally employable building technology graduates who will measure up to that of developed countries in the world, innovative teaching and learning methods that are participatory should be in vogue, while teachers need to stop being sages on stages, and become facilitators, motivators, guides and co-participants in the teaching and learning process. Today's education is more than acquiring knowledge from a single disciple such as building technology. Generic skills in form of communication, team work, problem solving and critical thinking are now more valuable fundamentally. Barbett (2011) suggested a move from the traditional curricular to what could be defined as emerging curricular in Table 3.

Table 3. Traditional versus emerging curricular

\begin{tabular}{ll}
\hline \multicolumn{1}{c}{ Traditional Curricular } & \multicolumn{1}{c}{ Emerging Curricular } \\
\hline Knowing that written communication & Knowing how oral communication \\
Personal & Interpersonal \\
Disciplinary Skills & Transferrable Skills \\
Intellectual Orientation & Action Orientation \\
Problem Making & Problem Solving \\
Knowledge as process & Knowledge as Product \\
Understanding & Information \\
Concept-Based & Issue-Based \\
Knowledge-Based & Task-Based \\
Pure & Applied learning and authentic real- \\
& world problems in classroom \\
Proposition-Based Learning & activities \\
\hline
\end{tabular}


Similarly, Majumdarin Oviawe and Adeola (2017) opined that there should be a paradigm shift in educational practice of teaching and learning in knowledge society. Majumdar suggested that where learning through facts, drill and practices, rules and procedures was more adaptive in earlier days, now learning through projects and problems, inquiry and design, discovery and invention, creativity and diversity, action and reflection is more fitting for the present times. Hence, there should be a shift in the dimensions of teaching and learning system in the knowledge society. The suggested shift needed in each of the pedagogical dimensions as an effective approach to build up generic skills and competencies embracing systematic process and content-rich teaching and learning methodologies is shown in Table 4.

Table 4. Traditional versus Emerging Curricular

\begin{tabular}{lll}
\hline \multicolumn{1}{c}{ Dimension } & \multicolumn{1}{c}{ Undesirable } & \multicolumn{1}{c}{ Desirable } \\
\hline Pedagogical Base & Instructive & Constructive \\
Learning Focus & Content & Learning to Learn \\
Learning Goal & External Controlled & Autonomous \\
Teacher Role & Didactic & Facilitative \\
Delivery Modes & Fixed & Open \\
Learning Structures & Rigid & Flexible \\
Instructional Models & Instructor-Centred & Learning Team Centred \\
Learning Models & Passive & Active \\
\hline Source: Malerich (2009). & &
\end{tabular}

Based on the table and facts given, the ability to circumnavigate the various disciplines and critically communicate, extract and evaluate what it means to acquire the needed features for individuals in the workplace to succeed successfully. Progressively, the most vital factor in modern times on education is not focused on the teachers passing information to the students and the students retaining such information. It is expected that the teachers educate their students on how to navigate, interpret and handle difficult concepts, ideas and concepts, act and think in line with expectations, produce insights that are creative and valuable for society's benefit. This highlights that education is entering a new and exciting period. Nigerian schools must shift their way of teaching to interactive based from fact based teaching, the objective of which is to foster the acquisition of durable skills in form of problem solving, develop an expert mind set and critical thinking. Teachers in Nigeria should learn to improve the experience of students and set the pace for development of education globally.

\section{Cooperative Learning Model}

Cooperation focuses on bringing two or more individuals together for the purpose of learning towards completing a given task. It could be in many forms: face-to-face, computer mediated (Computer Supported Collaborative Learning (CSCL), joint or labour divided, synchronous or asynchronous etc. Each form of cooperative learning is simply a mutual engagement of participants in a coordinated effort to solve a problem together (Lai, 2011). Cooperative learning involves activities such as reading, building, predicting, and mechanisms which include induction, deduction, and compilation. The by and large product of cooperative learning not personally based but an integrated ability of individuals to reflect on the same task. Using the variance abilities and skills of persons in their best dispositions to achieve a common goal underpins cooperatives intelligence while the extent to which these persons learn from each other on the delivery processes of the given task further highlights cooperative learning. Collaborative intelligence according to Markova \& McArthur (2016) has the capacity of a person to think with others towards 
accomplishing a unique project that matters to people in the group. However, collaborative learning and collaborative intelligence could be further detailed leaning on dynamic learning capacity.

The concept, the capacity to learn dynamically is an organizations ability to specifically modify, extend and create its knowledge base via reconfiguration of learning routines that exploit, retain and explore knowledge inside and outside organizational borders (Manley \& Chen, 2015; Lewin, Massini, and Peter, 2011; Lichtenthaler \& Lichtenthaler, 2009). Furthermore, integrating internal and external knowledge in dynamic learning capability require that opportunities for knowledge exploration, transformation, and exploitation are created and underpinned. To this end, Manley and Chen (2015), Lewin, Massini, \& Peter (2011) posited that knowledge exploration emphasizes individual identification of vital knowledge from sources external while combining with ideas generated internally from established learning routines, select thoughts via discussion, debate and analysis. Lewin, Massini, and Peter (2011) asserted that exploratory learning is when an organizational member recognise, analyse, acquire and process new knowledge vital for operating the business. The indispensable team skills of sharing explored information, ascertaining open communication, building relationship and achieving mutual understanding of the given task are realizable in cooperative adventures (Alashwal \& Abdul-Rahman, 2014; Eriksson, 2010). In addition, Manley and Chen (2015); Lewin, Massini and Peter (2011) posited that knowledge exploitation entails the applicability and integration of newly assimilated knowledge to reshape the outcome and satisfy emerging needs in projects/buildings while knowledge transformation balances the external and internal knowledge intake, hence linking exploratory and exploitation learning.

Manley \& Chen (2015) adopted the opportunities for knowledge exploration, knowledge transformation, and knowledge exploitation to create a circular model of dynamic learning which was refined to cooperative learning model. This model depicts that improvement in exploratory learning leads to an increase in transformative learning which also enhances exploitative learning, which effectively readjusts operational routines (how things are done). These improvements cumulatively impacts on performance outcomes, positive outcome invariably motivates to renew exploratory learning (Manley \& Chen, 2015). Although the Manley's cooperative learning model focused on infrastructure construction organizational project life cycle, the learning model could be adopted in building technology classrooms to enhance the advancement of generic skills in the students. A model is a representation, usually based on analogies, which are built contextualizing certain portions of a domain with a given goal. The representation according to Chamizo (2013) could be essential ideas, phenomenon or object generated by a person or group of people; analogy depicts similarity of properties or features in a model while specific goals are the purpose for which the model is proposed or designed.

Chamizo added that the purpose of the model is derived from the manipulation of its features to enable the learning of how and why it is first created. Cooperative learning model here represents prototypical flow of knowledge into the classroom environment from both the teacher and learners beyond boundaries of the classroom environment. Cooperative learning model in building technology proposes a learning approach that affords learners the opportunity to alter and create their knowledge base via reconfiguration of routines of learning which exploits, retain and explore knowledge both within and outside the school coverage. The purpose would be to make the learners active and creators of their own knowledge; exploit the developments within their personal environment thereby making an artefact creator out of every learner; and ultimately 
transform the approaches to tasks/projects, as a result improve outcome of the individual and his/her product.

The integration of cooperative learning model in teaching and learning building technology will alter the approach to instructional delivery practices on-going. By instructional delivery practices, one refers to course of action in which a teacher personalizes instructional approaches as it suits his/her expectations, learners, schools and workplace demands. It is a process by which teachers apply a repertoire of instructional strategies to communicate and interact with students around academic content, and to support students' engagement (California Community Colleges, n.d). Varieties and differentiations in instructional delivery practice afford the teachers opportunities to make teaching and learning relevant to actual-life issues which directly allow learners to explore, inquire, and create knowledge.

The explorative, transformative and exploitative aspects of cooperative learning model when utilized in classroom environment will open up learners' active participation, build on existing knowledge and skill, enhance creativity and imaginative skills, evaluate individual performances, integrate technological approaches, build effective teamwork and communication skills. All these are aspects of employability skills required in today's workplace.

\section{Integrated and Contextualized Learning Approach}

Generic skills are best learned when they are included among instructional goals and explicitly taught. These instructional goals need to reflect the full range of academic, technical and generic skills. Generic skills are best learned when classrooms replicate key features of real work settings and student tasks approximate those performed by workers in those settings. Here, emphasis is on contextualized learning rather than abstracted learning in artificial or unrealistic classroom settings. This reflects the increasingly widely held acknowledgement that the context for learning is crucial to its success.

Other methods suitable for learning generic skills in classroom context from literature are: learning by doing, experiential learning, e-learning (virtual learning), video conferencing, group work, role playing and class discussion to facilitate exploration of ideas and deeper understanding (OFTSED, 2007).

The need to inculcate employability skills into school graduates to meet the needs and demands of the dynamic workplace has remained a quest for possible solution in recent times. Employability skills are a broad set of knowledge, skills, work habits and character traits that are perceived by all stakeholders (teachers, school reformers, employers of labour and the society) to be essential to the success in the present day workplaces, particularly in collegiate programs, contemporary careers. Employability skills includes: critical thinking and problem-solving skills; communicative skills, information and media literacy skills, contextual learning skills, learning and innovation skills; cooperation/collaboration, research and information fluency; digital citizenship, technology operations and concepts (Partnership for 21st Century Skills [P21], 2011; Great School Partners, 2016). Kaufman (2013) posited amidst the variations and discrepancies concerning the definitions of generic skills and what constitutes these skills, the focus is fully on what students could do with knowledge and their effectiveness in authentic contexts. Similarly, Lai (2011) asserted that the much desired critical thinking, innovative and creative skills, technology friendliness etc, communication and collaboration skills are much desired; especially in building technology whose products/graduates are expected to work amidst team members as no one individual carries out a building project. The affordances of cooperative learning model are physically powerful force for employability skills which are essential for adaptability and development in the world of work. It is against this background that this study sought to identify the aspects of cooperative learning model for developing employability skills in building technology students. 
Every building technology graduates are expected to be able to secure employment, set up a self-reliant venture or pursue further education in building construction career. They are expected by employers of labour, construction contractors, educators, politicians and the world of work to possess flexible employability skills over basic skills. However, the result of the training offered to learners while in school fails to match up with the expectations of the world of work thereby leaving the graduates short of the employability skills (broad set of knowledge, work habits, character traits) perceived to be essential in the ever dynamic workplace. Schleicher (2012) reported that on the part of the students, there seem to be lack of awareness of these saleable skills and it is attributed to the fact that employability skills are neither taught explicitly nor assessed over factual retention. Consequently, the students are left to pick up employability skills by chance without a conscious design of the school system to inculcate these skills. Hence, the teachers' choice of instructional delivery strategies has favoured teacher-centred over learners-centred approaches and without a model to enhance problem-based, project-based, community engagement and cooperative strategies of learning which are much advocated for the actualization of employability skills inculcation in the students. It is against this background of failure to meet the need of equipping building technology graduates with the essential employability skills required in the ever dynamic world of work that this study is conducted to integrate cooperative learning model in building technology classrooms to facilitate the development of employability skills in students'.

\section{Creation of Well-equipped Learning Spaces}

Current forms of education need multi-functional, technology rich, high quality teaching spaces. The trend moving toward shared spaces for learning and learning in formal schools in the nation highlight the need to offer public spaces in the school and classroom which enables students to create a sense of belonging in a society. Also, spaces for library need to comprise different study and teaching spaces for learning which should be open to everyone across the schools. Providing spaces for social activities, collaboration and study should align with current modes of operation in the work place (Imperial College London, 2019). The increase in flexibility is influenced by the various requirements for students at various locations and this changes the need of the community all through the year. For instance, more work in groups is required at various times while studying individually happen during examinations. Nigeria should establish a future-looking approach to increase learning space as follows:

1. Creating flexibility in divisibility in flat spaces and technology, furniture can also be used to achieve flexibility.

2. Provide innovative spaces for learning in schools for facilitation and innovation to take place and offer a resource rich environment, adaptable environment for teachers to try new techniques for teaching.

3. Create a new policy framework for spaces to facilitate more shared policy and increase utilization.

4. Develop well equipped, modern, laboratories to facilitate idea generation and development of global leading innovative approaches to teach, with integration of ideas and experiences between students and teachers.

5. Maintain, enhance education resource common rooms to facilitate quality experiences for students.

6. Create spaces to help staffs and students generate and engage ideas.

7. Ensure library spaces fit and support students and staff by providing bookable spaces, data and power. 


\section{Enhanced Use of Technology}

Today's workplace requires the use of technology, therefore, the availability of technology and the competence of the teachers and students to use the technology become imperative. Digital advances will be applied to facilitate and foster more interesting ways to teach and learn. The mixture of digital and online technologies replaces classroom and lectures for pedagogical interaction and experiences. Researchers reveals digital interactive learning technology are specifically successful in enhancing students ability to learn (Ghadiri, Qayoumi, Junn, Hsu, \& Sujitparapitaya, 2013; Klochan, 2015; Oviawe, 2019). Advantages for the utilization of technology in education include gains in actual and collaboration feedback between teachers and learners. Through technology, teacher facilitation can be done ones and students from various locations in their numbers can connect and thereby gain in real-time, hence, saving energy and resources. Also, the feedback mechanism enables the teacher not only to monitor the progress of students' learning, but also to plan remediation and mitigate learning difficulties. The mixed learning combine face to face learning with online materials, freeing up time for more interaction in the classroom. Learners can be required to study materials online prior to classes to enable them prepare better for an interactive class session. This improves the opportunity for learners for interaction with themselves directly and the teachers as well as assessing materials developed all over the world. Knowledge and skills gained through this technology interactivity can be readily available and efficiently applied in providing services and gives the graduates of building technology comparable advantage over those that never had such opportunities.

\section{Inclusive Learning and Teaching Environment}

Nigeria need to create equal opportunities for her students by recognizing and harnessing learners' identity and experience while providing opportunity for students to learn one another and by so doing, making their differences assets rather than liabilities. Teaching and learning should facilitate the professional and personal sense of students and identify a sense of belonging in the field of building technology, which contributes to their success. Teachers should design various ways of assessment, learning and teaching which recognizes and support learners need as community members and individuals, eradicating barriers to creating and learning to help students acquire and possess generic skills of interpersonal relations, communication, and teamwork.

Students learn and work well in an all-inclusive learning and teaching environment which depends on the attitude of the teachers, interactive classroom community, curriculum content and appreciate the various opinions, cultural backgrounds, social interaction and orientation. Students in Nigeria have various cultural orientations and backgrounds which already calls for inclusive teaching and learnings learning and teaching atmosphere. Teachers should ensure students to be a part of the academic community that provide equal opportunity for everyone to succeed. This being the case, learning to operate in different workplaces prepare students to acquire the necessary skills and apply their knowledge practically despite the different cultures, values and experiences they acquire. This will result in mobility and adaptability of Nigerian trained building technology labour force.

\section{CONCLUSION}

While variations exist in the classification of generic skills, there is broad understanding of what qualities, knowledge and skills make up these skills required for graduates in today's world of work. Employers of labour expects graduates to possess the requisite technical and discipline knowledge, competencies and skills from their degrees but need graduates to demonstrate a range of broader skills and attributes that include team-working, communication and ICT usage, leadership, critical thinking, problem-solving, managerial 
abilities, interpersonal skills, among others. These generic skills should be integrated into the curriculum and taught to ensure that building technology students and graduates possess the needed skills by employers to coup in a global competitive world of work. Building technology educators/teachers need to employ appropriate approaches and teaching methods and environment to foster acquisition of these skills by their students. As the possession of these skills by graduates of building technology provide an easy process for employment, ticket to succeed in any environment and when they change jobs within the ever dynamic workplace.

\section{REFERENCES}

Ajuluchukwu, E. N. (2012). Assessment of minimum academic standards adopted by universities in South-East and South-South for undergraduate business education programmes. Unpublished thesis. Awka: Nnamdi Azikiwe University.

Alashwal, A. M. \& Abdul-Rahman, H. (2014). Aspects of project learning in construction: A socio-technical model. Construction innovation: Information, Process, Management, 14(2), 229-244.

Barbett, D. (2011). Partnering industry and education for curricular enhancement: A response for greater educational achievement. Online journal of workforce education and development, 5(2), 14-20.

Bennett, T. M. (2006). Defining the importance of employability skills in career/technical education. Dissertation. ProQuest Information and Learning Company.

California Community Colleges (n.d). Basic skills as a foundation for student success in California Community Colleges - Part 1: Review of literature and effective practices. Retrieved from: www.cccbsi.org/websites/basicskills/

Chamizo, J. A. (2013). A new definition of model and modelling in Chemistry teaching. Science and Education, 22(7), 1613-1632.

Eriksson, P. E. (2010). Partnering: What is it, when should it be used, and how should it be implemented? Construction management and Economics, 28(9), 905-917.

Federal Republic of Nigeria (2013). National policy on education. Lagos: NERDC.

Ghadiri, K., Qayoumi, M., Junn, E., Hsu, P., \& Sujitparapitaya, S. (2013). The potential of blended learning using MIT edX's 6.002x Online MOOC content combined with student team-based learning in class. Retrieved from: https://www.edx.org/sites/default/files/upload/ed-tech-paper.pdf

Greatbatch, D., \& Lewis, P. (2007). Skills and learning intelligence module. 10 South West observatory.

Ikoro, I. S., \& Ezeanyim, U.E. (2017). Basic education in Nigeria for global competitiveness: The way forward. International journal of advance research and publications, 1(5), 304-307.

Imperial College London (2019). Innovative teaching for world class learning and teaching strategy. Retrieved from: https://www.imperial.ac.uk/media/imperialcollege/about/leadership-and-strategy/vpeducation/public/LearningTeachingStrategy.pdf

Kaufman, K. J. (2013). Ways to $21^{\text {st }}$ century skills: Why students need them and ideas for practical implementation. Kappa Delta Pi Record, 49(2), 78-83.

Keser, H. Y. (2015). Effects of higher education on global competitiveness: Reviews in relation with European countries and the Middle East countries. Annals of the "Constantin Brancusi" University of TarguJiu, Economy Series, 1(1), 58-68.

Klochan, Y. (2015). Highlights from 'blended learning on MIT's campus'; Now 16 xTalk/office of digital learning. Retrieved from: https://odl.mit.edu/newsevents/blog/highlights-blendedlearning-inits-campus-nov-16-atalk 
Lai, E. R. (2011). Collaboration: A literature review. Research report, Pearson's publications in pdf format. Retrieved from: http://research.www.pearsonassessments.com

Larson, L., Miller, T., \& Ribble, M. (2010). 5 considerations for digital age learners. Learning and leading with technology, 37(4), 12-15.

Lewin, A. Y., Massini, S. \& Peters, C. (2011). Micro foundations of internal and external absorptive capacity routines. Organization Science, 22(1), 81-98.

Lichtenthaler, U., \& Lichtenthaler, E. (2009). A capacity-based framework for open innovation: complementing absorptive capacity. Journal of management studies, 46(8), 1315-1338.

Malerich, J. (2009). The Value of International Internships in Global Workforce Development. Arizona: Arizona State University.

Manley, K. \& Chen, L.E. (2015). Collaborative learning model of infrastructure construction a capacity perspective. Construction innovation, 15(3), 355-377.

Markova, D., \& McArthur, A. (2016). Collaborative intelligence: Thinking with people who think differently. Park City: Professional Thinking Partners. Retrieved from: www.cqthebook.com/thebook.

National Board for Technical Education (2007). Curriculum for Building Technology. Kaduna: NBTE Press.

Nwaoku, N. A., \& Tom, A. (2009). Nigeria's tertiary education curriculum in the $21^{\text {st }}$ century: The implications and challenges. Journal of curriculum organization of Nigeria, 3(1\& 2), 5-17.

Ocho, L. O. (2010). Professor Benneth Ukeje memorial lectures. The annual conference of the Faculty of Education. Awka: Nnnamdi Azikiwe University.

OFSTED. (2007). Developing social, emotional and behavioural skills in secondary schools: A five-term longitudinal evaluation of the secondary national strategy pilot. London: OFSTED.

Olatunji, O. (2009). The Nation newspaper. April $11^{\text {th }}$.

Omollo, A., Nyakrura, B., \& Mbalamula, Y.S. (2017). Application of participatory teaching and learning approach in teacher training colleges in Tanzania. Journal of scientific research and reports, 16(6), 1-10.

Oviawe, J. I., \& Adeola, L. K. (2017). Workplace skills in technical education as a catalyst for producing employable graduates in the $21^{\text {st }}$ century. IOSR Journal of Research and Method in Education (IOSR-JRME), 7(3), 1-8.

Oviawe, J. I. (2019). Effects of Blended Learning Approach and Students' Academic Performance Blocklaying and Concrete Works Trade in Technical Colleges in Edo State, Nigeria. International Journal of Educational Benchmark (IJEB), 12(1), 45-53.

Partnership for $21^{\text {st }}$ century skills (2011). Framework for 21st century learning. Retrieved from: http://static.battelleforkids.org/documents/p21/P21_Framework_Brief.pdf

Sargsyan, A. (2017). Variety of approaches in assessment of global competitiveness. International journal of economics and management sciences, 6(1), 47-59.

Schleicher, A. (2012). Preparing teachers and developing school leaders for the $21^{\text {st }}$ century lessons from around the world. Paris: OECD.

Shafie, L. A., \& Nayan, S. (2010). Employability awareness among Malaysian undergraduates. International journal of business and management, 5(8), 119-123.

Smith, E., \& Kruger, J. (2008). A critical assessment of the perception of potential graduates regarding their generic skills level. SAJEMS, (11), 122-138.

Weligamage, S. S. (2009). Enhancing employability through quality assurance. Sub Theme A - Enhancing Employability through Quality Assurance - ASAIHL. Retrieved from: https://bit.ly/2zpkNZc 